\title{
КОРНІЙ МІАІЯ
}

Аоктор мистецтвознавства, професор, провіАний науковий співробітник віААілу екранно-сценічних мистецтв та культурології Інституту мистецтвознавства, фольклористики та етнології ім. М. Т. Рильського НАН України

\section{KORNIY LIDIYA}

a Doctor of Art Studies, a professor, a chief research fellow at the Department of Screen-Stage Arts and Culturology of the NASU M. Rylskyi Institute of Art Studies, Folkloristics and Ethnology

\section{Бібліографічний опис:}

Корній, $\Lambda$. (2021) Українська шкільна різдвяна Арама XVII-XVIII ст. і Аяльковий театр вертеп: проблема аАаптації та інтерпретації музичного чинника. Народна творчість та етнологія, 2 (390), 5-14

Korniy, L. (2021) Ukrainian School Christmas Drama of the XVIIth-XVIIIth Centuries and Puppet Nativity Play Theatre: Problem of Adaptation and Interpretation of a Musical Factor. Folk Art and Ethnology, 2 (390), 5-14

\section{УКРАЇНСЬКА ШКІАЬНА РІЗАВЯНА АРАМА ХVII- XVII СТОАІТТЯ І ЯЯ ЬКОВИЙ ТЕАТР ВЕРТЕП: ПРОБАЕМА АААПТАЦЇ̈ ТА ІНТЕРПРЕТАЦЇ̈ МУЗИЧНОГО ЧИННИКА}

\footnotetext{
У статті йдеться про те, що українське мистецтво бароко розшарувалося на високий, сереАній та низовий стимьові рівні. Проблема зв'язку між різними стильовими рівнями українського музичного бароко ще не привернула належної уваги дослідників. У розвідці розгляАаються впливи української шкільної різдвяної Арами XVII-XVIII ст. на мяльковий театр вертеп. Наголошується, що вперше проводиться порівняння цих Авох видів театрального мистецтва з погляду використання в них музичного чинника. Установлено, що 1-ша Аія вертепу пов'язана з високим стилем української різАвяної шкільної Арами. Це розкрито на основі аналізу драматургічних функцій Хору в шкільній Арамі та вертепі. Хор у цих видовищах брав активну участь у розкритті різАвяного сюжету, виконував роль персонажа. Спільним Аля них був жанр духовного канта із силабічним віршуванням. Попри схожості з високим стилем шкільної драми, вертеп був новим театральним жанром, який відносимо до сереАнього стильового рівня. Орієнтуючись на народне середовище, автори вертепу дохіАливо Аоносили до широкого гляАача сакральний сюжет. ВіАзначається, що в 2-й Аії вертепу були адаптовані інтермедії шкільних драм, які представмяли низовий стильовий рівень бароко. У цій дії на перший план виходила сміхова мінія, музичний компонент позначений впливами українського музичного фольклору 3 перевагою танцювального. Взаємодія фолькцору з низовим варіантом бароко мала великий потенціац Аля подацьшого розвитку українського національного театру. ЗавАяки тому, що музика була невіА’ємною частиною мялькового вертепу й віАігравала важливу Араматургічну функцію, це театральне видовище, як і деякі шкільні драми, мало ознаки жанру «драма з музикою». Отже, шкільна Арама і вертеп створювали підгрунтя, на якому в ХІХ ст. виникла українська Араматургія зі значною ромю в ній музичного чинника, що по суті була «драмою з музикою».
}

Ключові слова: вертеп, шкільна драма, інтермедії, канти, адаптація, спів Хору, стильові рівні бароко. 
The article states that the Ukrainian baroque art has become differentiated into the high, middle and lower stylistic levels. There were certain connections between them, and new art genres appeared on the verges of these levels. The problem of the connection between distinct stylistic levels of the Ukrainian musical baroque has not yet attracted the attention of researchers. The study examines the links between the Ukrainian school Christmas drama of the XVIIth- XVIIIth centuries and the puppet Nativity play theatre.

It is noted that for the first time a comparison of these two kinds of theatrical art is drawn in terms of the use of a musical factor in them. It is established that the first act of the Nativity play drama is related to the high style of Ukrainian Christmas school drama. This is revealed on the basis of analysing the dramatic functions of a Choir in both school drama and Nativity play drama. A choir in these spectacles took an active part in revealing the Christmas story, playing the role of a character. What they had in common was the genre of spiritual chant with the syllabic versification. Despite its association with the high style of school drama, the Nativity play drama was a quite new theatrical genre that belongs to the middle stylistic level. Focusing on the folk environment, authors of the Nativity play drama intelligibly conveyed to a wide audience the sacred plot. It is noted that in the second act of the Nativity scene were adapted interludes of school dramas, which represented the lower stylistic level of the Baroque. In this act, a funny line came to the fore, and a musical component is marked by influences of the Ukrainian musical folklore with a predominance of its dancing variety. The interaction of folklore with the lower version of the Baroque had a great potential for the further development of the Ukrainian national theatre. Due to the fact that music was an integral part of the puppet Nativity play drama and played an important dramatic function, this theatrical spectacle, like some school dramas, had the features of the drama with music genre. Thus, school drama and Nativity play drama created the foundation, on which in the XIXth century, the Ukrainian dramaturgy emerged, with a significant role of the musical factor in it, which was essentially a drama with music.

Keywords: nativity play, school drama, interludes, chants, adaptation, singing of a Choir, baroque style levels.

Нові наукові віАкриття, нове світосприйняття, що в загамьноєвропейському масштабі припами на Аобу бароко, позначимися на розвитку різних галузей мистецтв. Бароко в Україні, як і в Європі загалом, розшарувалося на високий, сереАній і низовий стимьовий рівні. Утім, ізольованими вони не були, між ними виниками певні зв'язки, і на межі цих рівнів з'являлися нові мистецькі жанри [13, c. 30 ].

Ао високого стимьового рівня бароко в українській музиці намежала церковна музика - багатоголосні твори (партесний концерт). СереАній стимьовий рівень - кантовий жанр, пов'язаний із виникненням в українській мітературі поезіі із симабічним віршуванням (високий рівень). Кант розвивався піА впливом цієї поезії, але на ньому також позначимася рецепція українського музичного фолькмору та інонаціонацьних пісенних жанрів. Цей жанр з'явився в колах професійно освічених $ю$ юй, а також в аматорському середовищі (бурсаків, мандрівних Аяків). Низовий стильовий рівень - це музичне мистецтво світського напряму, яке використовувало український музичний фомькмор, але при цьому не було з ним тотожним. Проблема зв'язку між різними стильовими рівнями українського музичного бароко ще не привернула належної уваги АосміАників.

ПрикмаАом зв'язку між високим (професійним) і низовим стимьовим рівнями може бути хоровий твір XVIII ст. світського змісту «Сначама Анесь по утру рано, хто в вечеру пьян бым». У його вербамьному змісті змацьована гумористична картинка, а в музичному тексті невіАомий автор використав стимістику професійної багатогомосної церковної музики XVII-XVIII ст. (партесного концерту) [17, с. 101-126]. ЗавАяки поєАнанню високого і низового стимьових рівнів виник новий жанр - пародійний хоровий концерт. Зіткнення різних стимьових рівнів бароко можна простежити і в українському театрахьному мистецтві, яке в цю епоху представлене шкільною Арамою та мяльковим театром вертепом.

Наприкінці XVIII ст. унасліАок освітньої реформи Самуїла Миславського в Київській акалемії (1783-1796) шкімьні вистави було заборонено. Це зупинимо розвиток націонамьного театру, який віАновився тікьки на початку XIX ст. в Помтаві. ТраАиції шкімьної

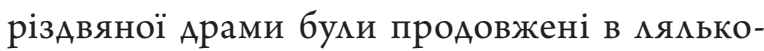
вому театрі - вертепі. 
Українська шкільна Арама XVII-XVIII ст., що розробляма Ауховну тематику (різАвяну, великодню та ін.), належить Ао високого сти$\Lambda$ ьового рівня бароко. Цьому рівневі віАповіАав високий стиль вислову, використання символіки, алегорій тощо. Авторами Арам були професори курсів поетики та риторики Києво-Могилянської академії, і в цьому середовищі формувався український професійний театр. Саме звіАти походять збережені тексти шкільних Арам. У шкільних Араматичних виставах, як показало наше Аослідження, важливу Араматургічну роль віАігравав музичний компонент [6, с. 24-66]. Про це свідчать вербальні тексти музичних номерів драм. На жамь, їх нотних записів у текстах Арам немає, проте Аеякі з них можна віднайти в нотних рукописах кантів.

У виставах шкільних Арам Аля віАпочинку глядачів виставляли інтермедії, які відповіАали низовому стильовому рівневі бароко. Вони маки світський зміст, переважно гумористичного характеру, написані були простою, розмовною мовою. Отже, у шкільних виставах відбувалося зіткнення високого стильового рівня бароко (серйозна частина Арами) з низовим (інтермеАіï), між якими переважно не бумо зв'язку.

БАизький за змістом Ао шкільної різАвяної Арами був Аямьковий театр вертеп. Його 1-ша Аія розробляла ту саму різАвяну тематику, що й шкільна Арама, але у вертепі вона реалізувалася в новому жанрі - $я$ жьковому театрі, що став попукярним у міському середовищі. Існує різна іАентифікація вертепу. Аеякі досліАники віАносили вертеп до народного театру $[16$, с. 16]. М. Петров вважав вертеп напівшкімьною, напівнародною виставою $[12$, с. 10]. ВіАзначалися й зв'язки вертепу з українською шкільною різАвяною Арамою. Зокрема, $\Lambda$. Махновець писав, що за розробленням теми про народження Христа вертеп близький Ао різАвяної шкільної драми Аимитрія Туптака та Митрофана Аовгалевського [10, с. 88]. Проте вказувалося й на Аеякі віАмінності між вертепом та різАвяною Арамою в розкритті різАвяної тематики. Тексти вертепного Аійства, на віАміну віА різАвяної Арами, не містили розмогих риторично-богословських монологів, не були переобтяжені амегорією і сентенціями. У них не брали участі амегоричні персонажі $[14$, c. 705$]$.

Порівняння вертепного Аійства 3 різАвяною шкільною Арамою з погляАу ролі в цих виставах музичного чинника досі не проводилися. Така розвідка дає змогу розкрити специфіку зв'язків цих Авох виАів театрального мистецтва, виявити ї схожості та відмінності, а також установити особливості аАаптації різАвяної шкільної Арами в

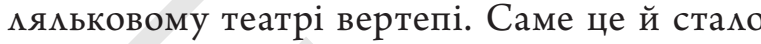
преАметом наших стуАій.

АосліАники припускали, що вертепне Аійство в Україні виникло в XVI ст., але Аокументальне піАтверАження про вертепні вистави в Україні існує тікьки з Аругої половини XVII ст. Про вертеп згадується в матеріалах $\Lambda$ ьвівського Ставропігійського братства. У його прибутковій книзі піА 1666 роком зафіксовано кошти, які призначалися столярові на спорудження вертепу та художникові на Аекорації до нього [2, c. 489-490]. ОАнак із зазначеного часу не збереглося жодних текстів вертепної драми. Обмаль відомостей і з XVIII ст.

Сере А документів Київської акаАемії в рукописі піА 1779 роком в «Актах і документах» цього закладу вміщене «Правило увъщате ььное къ піаницамъ», у якому є згаАка про вертепну Араму як поширене явище. У ньому зазначається: «РаАуйтеся пиворьзы и паки реку радуйтеся. Се радости Аень приспьваеть, день - глаголю - праздника Рождественскаго зближается. Востаньше убо отъ можей своихъ и воспримъте всякъ по своему художеству оруАія: сАБлайте вертепы, скмейте звъзду, составте партесы! ЕгАа же станете по умицахъ со звукомъ броАить, ищуще сивухи, приймуть васъ казаны во кровы своя» [1, с. 83].

3 XVIII ст. Ао нашого часу Аійшло тільки три тексти вертепної Арами. Ава з них неповні: $€$ Аише окремі виписки гущинського Аяка 
Іоанна Аанимовича віА 1771 та 1776 років і вертеп 1790 року українсько-польською мовою без початку $[8$, с. 6].

Повний текст вертепного Аійства наведено у так званому Сокиринському (Галаганівському) вертепі. Його вцасником був Г. П. Гамаган. Текст вертепу з нотами, за свідченням Г. П. Гамагана, у 1770 році київські бурсаки занесли в маєток його прадіда в с. Сокиринці колишнього Прилуцького повіту на Полтавщині (нині Чернігівської області), Ае вони ставими вертепне Аійство. ВіАтоді в маєтку Галаганів вертеп виставцявся систематично. 3 тексту Сокиринського вертепу робими списки. ОАин з них мав український історик Микола Маркевич. Його словесний текст опублікував I. Аавиденко в 1860 році [11, с. 27-64]. У 1882 році Г. П. Галаган налрукував текст вертепу з нотами за списком 1875 року [3, c. 1-38]. Пізніше список Сокиринського вертепуз нотами, який зберігався спочаткув Прилуцькому краєзнавчому музеї, а потім в Українському театральному музеї, опублікував Є. Марковський [8, с. 40-111]. Це найповніший текст вертепного Аійства, пов’язаний з Галаганівським осереАком і, що особливо важливо, у цій публікації подано нотні тексти музичних номерів [9, с. 1-40] ${ }^{1}$, яких немає у виАаних текстах шкі ььних різАвяних Арам. У порівняльних досліАженнях ми послуговувалися вербальним і нотним текстом Сокиринського вертепу, виданим Є. Марковським, а також текстами відомих різАвяних Арам XVII-XVIII ст., зокрема «Комедіи на день Рождества Христова» Аимитрія Туптала, яка найдетальніше розкриває різАвяну тематику.

У Авох Аіях вертепу використовувався музичний чинник. У виставі брав участь чотири- або п'ятиголосний хор та інструментальний ансамбль. У 1-й Аії вертепу, як і в шкільній різАвяній Арамі, розроблялися теми про міниивість світу та гординю Ірода, його владолюбство, за що він зазнав покарання. У цій Аії мялькової вистави брали участь такі персонажі: Пономар, Ангец, три східні
Царі, пастухи, ІроА, Воїни, Чорт, Смерть. Музичний компонент преАставлений співами Хору, і тільки наприкінці 1-ї дії звучав інструментальний номер «Аудочка».

Наше попереАнє АосліАження музичного чинника в українській шкільній Арамі XVIIXVIII ст. показано, що в біньшості Арам Хор активний учасник Аійства і виконує функцію персонажа. Були встановлені різні Араматургічні функції Хору в Арамах. Як з'ясувалося, щодо використання музичного чинника в Арамах українські автори спиралися на теорію катиномовних поетичних курсів, що викладалися в Києво-Могилянській акаАемії. Автори цих курсів, характеризуючи жанр трагеАії, комедіï, трагеАокомеАії, писа$\Lambda$ и про роль Хору в цих творах, конкретизуючи його функції. При цьому вони спирахися на світську Аавньогрецьку трагедію та на трактати ітанійських гуманістів [6, с. 24-32]. Українські автори цих курсів, які часто самі писали Арами, переносили положення щодо використання Хору в Арамі в практику українського шкікьного театру.

Як показав аналіз 1-ї дії Сокиринського списку, у вертепі, як і в більшості різАвяних Арам, музичний чинник преАставлено переважно співами Хору (a capella). У шкільній Арамі Хор виступав на сцені або за сценою, а в $я$ яьковому театрі - за вертепною скринькою. Тексти співів Хору у вертепі дають можливість стверАжувати, що важливу араматургічну роль Хору постановники вертепного Аійства запозичили з різАвяної Арами. Співи Хору в тексті Сокиринського вертепу позначені як «пьснь» (пісня). За версифікаційними та музичними особливостями ці пісні мають ознаки жанру канта.

Загалом канти фіксувалися у вербальних та нотних рукописних збірниках, а також розповсюАжувалися усним шляхом. Їхніми авторами були преАставники освічених середовищ, Ае навчали музичної грамоти (братські школи, Київська академія, колегіуми). Аля кантів характерна пісенна мелоАика $з$ мінімальною розспівністю складів, терцієвий викмаА мелодії Авома верхніми 
голосами, а інші Ава-три голоси створюють акордову фактуру. Канти мають чітку структуру, в якій простежується становлення найпростіших музичних форм - періоду повторної буаови, періоду піАсумовуючого типу, Авочастинної форми, а в основі хорової фактури пісень закмадена функційна гармонія киасичного типу.

Зіставлення віАнайдених нами музичних номерів різАвяних шкімьних Арам, наприкмаА, «Аггенъ пастырем въстиль», «Гкасъ слышав - в Раме Рахили рыдаше», «Нынь весь мир Аа играеть» 3 «омеАіи на день Рождества Христова» Аимитрія Туптала та пісень, зафіксованих у Сокиринському вертепі, показало, що вони належать Ао спімьного жанру - канта. Тобто в 1-й Аії вертепу використовувався той самий музичний жанр, що й у шкімьній різАвяній арамі.

Розглянемо Араматургічну роль Хору у вертепі детацьніше. У словесному тексті вертепу пісні позначені окремими номерами. Пісні, що вхоАИли ао оАнієї, іноАі Авох з'яв, які розроблями оАин сюжетний мотив, мали музичну єАність, що створювалася за принципом куплетної форми. На основі музичного змісту першої пісні співалися інші пісні на нові тексти. Між цими піснями могли бути Аіалоги персонажів або вони виконувамися піАряА. Такий скмаА пісень називаємо «музично-тематичним блоком».

Перша з'ява 1-ї Аії вертепу починається співом Хору «Пьнію время и молитвь часъ / Христе рожАенный спаси всьхъ насъ», який віАіграє функцію прологу. Приходить Пономар і в словесному виступі сповіщає про народження Iсуса Христа, Азвонить і віАходить. Протягом усієї першої з'яви Хор співав за вертепною скринькою, а на сцені не було жодного Аійства. Можмиво, що на Аругому поверсі вертепної скриньки, Ае мами перебувати священні особи, умаштовуваци сцену, яка імітувама народження Ісуса Христа. Так, наприкмаА, у тексті іншої версії вертепу Іоанна Щербини $\epsilon$ така Аописка: «Въ верхнемъ этажь горящія свъчи, и освъщают фонъ, гА⿱ преАполагается комыбель Спасителя; наАъ этим мъстом сіяніе; но ни ммаАенца, ни рожАшей не виАно» $[8$, c. 40$]$.

У першій з'яві Хор виконував чотири пісні: «Ангемы снижайтеся ко земли сбмижайтеся», «Небомъ земля сталася», «Какъ Ауциферъ памъ съ неба», «Бог отъ Аъвы ражАается» («музично-тематичний блок» № 1). У піснях означеного блоку розробляється сюжетний мотив про зближення земмі 3 небом через народження Ісуса Христа. Цим самим сюжетним мотивом розпочиналося розкриття різАвяного сюжету і в «КомеАіи на Аень РожАества Христова» Аимитрія Туптама. Хор у цій з'яві вертепу має сповіщзальну функцію, він розповіАає про події, які вже віАбулися. МелоАика пісні має оповіАний характер, а на слова «весемитеся, радуйтеся, яко съ нами Богъ набуває вемичності. ПіА впливом першої вертепної пісні Григорій Сковорода створив свою пісню «Ангелы, снижайтеся, ко земнь сближайтеся», яка ввійшла Ао його цикму «СаА Божественних пісень $\gg[4$, с. 54$]$.

Перша пісня відіграє важмиву ромь у створенні музичної єАності всієї 1-ї Аї. Вона $\epsilon$ своєріАною «темою», яка розвивається в інших піснях цієї Аї. Перші Ава такти становмять «яаро», 3 якого «виростають» музичні побудови інших пісень. Вони мають різний музично-образний зміст віАповіАно Ао Араматургічної ситуації. В основі цього «яАра» - початкова поспівка $(\mathrm{b}-\mathrm{d})$ з оспівуванням нижнього, а іноАі й верхнього звука, яка гармонізується в піснях 3 маАовою перемінністю g-moll - B-dur (I -V VII нат. = V Ао III ст.).

У Аругій з'яві у вертепі беруть участь Ава Ангели. ОАин 3 них звертається до пастухів зі сповіщенням про народження Iсуса Христа і закмикає ї славити Спаситемя. За вертепною скринькою чути розмову Авох пастухів (Грицька і Прицька), які збираються навіАати народженого Iсуса. Хор співає три пісні: «Слава буАи во вышнихъ Богу», «Вомъ и оселъ Христа витаютъ», «Ты вертепе возвеселыся» («музично-тематичний 
блок» № 2). У цих співах, розповідаючи про різавяні поАії, Хор виконує сповіщальну та панегіричну функції. У мелодиці пісень блоку віАтворено веселий і радісний настрій, якому сприяє мазуркова ритміка. Пісня «Слава буди во вышнихъ Богу, Аающему радость премногу» виникла піА впливом євангельської оповіді віА Иуки. Як зазначено в Євангелії, з ангелом з'явилася «сила велика небесного війська, що Бога хвалили й казали: "Слава Богу на висоті, і на землі мир, У євангельських слів з'явився церковний піснеспів - стихира «С $а$ ава во вишних Богу и на земли мир». Саме цей піснеспів використав у тій самій сюжетній ситуації Аимитрій Туптало в Арамі «КомеАіи на день РожАества Христова». ПіА впливом Євангельського тексту виникали й канти. Невідомий автор вертепу використав власне жанр канта.

У третій з'яві Ава пастухи вітають нароАженого Ісуса Христа у вертепі, Аарують йому ягня. ВіАтак співає Хор. У чотирьох піснях: «Нова рада стала», «Ае Христосъ родывся», «ПереАъ тимъ Аытяткомъ», «Прошу тебе, Царю» («музично-тематичний бкок» № 3) він виконує резюмуючу та панегіричну функції. Пісня «Нова рада стала» (з усіма купцетами, але з іншою мелоАією)поширилася в Україні й виконується піА час колядування на Різдво в різних регіонах України. Ремарка в кінці з’яви вказує на звучання танцю «Аудочки», який виконують пастухи піА інструментальний супровіА: «Музыка играет АуАочку. Пастухи танцуютъ и приговариваютъ: “Зуба зуба на сопилку”». Це був український танець 3 гопачковим ритмом.

У наступних з'явах розробцяються сюжетні мотиви, пов'язані переважно з Аіянням Ірода. У піснях «Анесь Иродъ грядетъ (четверта з'ява) та «И вицьвъ же онъ во своемъ повити» (п'ята з'ява), що мають оАнаковий музичний зміст («музично-тематичний блок» № 4), Хор сповіщщає про піАступні плани Ірода вбити новонародженого Iсуса шляхом знищення всіх немовлят. Нотний текст цих пісень $є$ музичною модифікацією пісні «музично-тематичного блоку» № 1 Аля відтворення Араматизму ситуації. У мелодиці монотонно повторюється тритактова фраза, і звучання набуває суворого характеру.

У шостій з'яві йдеться про трьох Царів (волхвів), які прийшли поклонитися немовмяті Ісусові, та про їню зустріч з Іродом, котрий прагне довідатися про місце перебування новонародженого. Царі віАвіАують Ісуса й піАносять йому Аари. Про всі події цієї з'яви співає Хор, виконуючи роз'яснювальну функцію: «ШеАше тріе Цари ко Христу со Аари», «Отвъщаша Ему идемъ къ рожАенному», «Азъ шеАъ покмонюся предъ царемъ смирюся», «ЗвъзАа идетъ чуАно съ востокъ на полудно» («музичнотематичний блок» № 5).

ПоАібну роз'яснювальну Араматургічну функцію виконує Хор і в сьомій з'яві. На ii початку Ангел намовляє Царів не йти Ао Ірода й показує їм іншудорогу. Про це йдеться упіснях хору: «Ангелъ къ нимъ вђщаетъ», «Волхвы возвратишася въ Ирода не быша», «Пришли въ страны своя Христа славословя». Ці пісні створюють «музично-тематичний блок» № 6. У ньому використано нотний текст «музично-тематичного блоку» № 5 . Завершується з'ява гнівним виступом Ірода, який, не отримавши вістей віА Царів, погрожує вбити новонародженого.

У восьмій та Аев'ятій з'явах ідеться про змовісний наказ Ірода вбити мамих Аітей, який виконують воїни, а також про опмакування матерями немовцят. У розкритті цієї сюжетної ситуації активну участь бере Хор, виконуючи пісні «Перестань рыдати печальная мати», «Иродъ несытый велитъ убити», «Не плачъ, Рахиме, виАя чадо неживе» («музично-тематичний блок» № 7). У цих піснях, за наявності певної інтонаційної подібності з музичними номерами попереАніх з'яв, переАано інший музично-образний зміст. ВіАповіАно до тексту музичне звучання має благально-скорботний характер. У пісні «Перестань рыдати печальная мати» Хор заспокоює матерів - 
«за живота страту пріемлють заплату». Після сцени вбивства воїном Аитяти Рахіли, їі плачу Хор у пісні «ИроАъ несытый вемитъ убити» висловлює співчуття матерям, а в наступній пісні - «Не плачъ Рахиме» сповіщає, що Аіти в небесному царстві «процвітають». У цих піснях Хор виконує співчувально-оплакувальну функцію. Хорові співи в такій самій Араматичній сюжетній ситуації, 3 такою ж Араматургічною функцією використовувалися й у різАвяній шкільній Арамі. Прикладом цього можуть слугувати співи Хору «О серАце, серАце, тверАЂйшо опоки! «Гасъ слышавъ - в Раме Рахими рылаше» У Аесятій з'яві «КомеАіи на Аень РожАества Христова» Аимитрія Туптала.

На Аесяту - тринаАцяту з'яви припаАає покарання Ірода. Він хотів жити вічно, але віАчув, що приходить «кончина». ОАнак Iрод не хоче зАаватися, прагне воювати зі Смертю й наказує Воїнам їі спіймати. Хор бере активну участь у розкритті цієї сюжетної ситуації («музично-тематичний блок» № 8). У пісні «Туть смерть выходить рече къ нему вину» йАеться про події, які буауть віАбуватися в наступній з'яві - поява персонажа Смерті, котра осуажує Ірода за його змочин. Ірод хвалиться своєю величчю й намагається Аомовитися зі Смертю, аце вона АовоАить свою могутність і січе Ірода косою. Цю ситуацію коментує Хор у пісні «Аерзай отъ смерти посьченъ косою», засуАжуючи Аіяння Ірода. Чорт відносить мертвого Iрода. Після цього звучить пісня, котра завершує 1-шу Аію: «Не въдацъ же он что вже истребится», у якій озвучена основна тема вертепного Аійства, - міниивість світу. Пісня виконує резюмуючу, морально-дидактичну функцію. Таку саму Араматургічну функцію виконує спів хору «О горАость мира! Что се сотворима?» у завершенні різАвяної Арами Аимитрія Туптала «Комедії на Аень Рождества Христова».

Порівняно 3 різАвяною шкільною Арамою, співи Хору у вертепі звучами значно частіше. Хор брав участь майже в усіх з'явах (у Аванадцяти 3 наявних тринадцяти), а в окремих 3 них виступав мише Хор (Аруга, четверта, п’ята з'яви). Автори різАвяних Арам іноАі замуча и Ао вистав церковні піснеспіви, що віАповіАами святу РізАва Христового, а в 1-й Аї Сокиринського вертепу звучами тімьки Ауховні канти.

Анаціз використання музичного чинника у вертепі показав, що 1-ша Аія пов'язана 3 високим стилем різАвяної шкільної Арами. Це проявилося в Араматургічних функціях Хору. Хоча він перебував за вертепною скринькою, він виконував ті самі Араматургічні функції, що й у різАвяній Арамі роз'яснювацьну, сповіщахьну, коментуючу, резюмуючу, засуджувальну, співчувально-оплакувальну та морацьно-Аилактичну. Тобто Хор у вертепі, як і в різАвяній Арамі, виконував ромь персонажа.

Попри зв'язки вертепу з високим стимем шкільної Арами, що яскраво проявилося в його музичному чиннику, він був новим театрацьним жанром, який віАносимо до сереАнього стильового рівня Бароко. Орієнтуючись на народне середовище, автори Аоносими Ао широкого гмяАача сакрамьний сюжет у АохіАливій формі в Аещо спрощеному викиаАі.

У 1-й Аї вертепу простежуються ознаки наскрізної музичної драматургї. Про це свіАчить розвиток музичного «тематизму» 3 оАного яАра, трансформація музично-образного змісту, зумовлена змінами сюжетної ситуації. Усе це вказує на намежний музично-професійний рівень невідомого автора музики вертепу.

Вертеп у 2-й Аії аАаптував інтермеАії шкільних різАвяних Арам. Ао нашого часу Аійшла невемика частина текстів інтермеАій, які виконувалися в шкільному театрі. Як засвіАчують ці тексти, в інтермеАіях також використовувався музичний чинник, але значно ріАше, ніж в основній частині різАвяної Арами. На жамь, нотних записів музичних номерів інтермеАій немає. Тому особмиво цінними $є$ нотні записи музичних номерів 2-ї Аї вертепу в Сокиринському списку. 
Вони можуть Аати певне уявлення про особливості музики, яка звучала і в інтермеАіях.

$\Lambda$ ітературознавці відзначали, що інтермедії шкільних Арам та 2-га Аія вертепу мало чим віАрізнялися. Основним завданням цих вистав було розважити й потішити гАяАачів. Вони розробляли схожі (здебіньшого кумеАні) анекдотичні сюжетні ситуації, подібним був і персональний скмаА Аійових осіб. СереА них - преАставники українського народу: козаки (запорожець), семяни, а також цигани, євреї (жиА-корчмар), поляки, митвини, москалі та ін.

Автори вертепу запозичими віА шкільних інтермедій Араматургічну будову вистави словесні виступи персонажів перемежовуваАися їхніми піснями й танцями, а іноАі вони виступали дуетом. Музичні номери створювали характеристику героїв, розкривали їхні почуття й наміри. Українським та інонаціональним персонажам намагалися надати національного колориту, що проявлялося в їхній мові, а також у музиці.

У цих видовищах (інтермеАії Арам та увертепі) виведено національного героя козака, що турбується про Аолю України. Це переАано в пісні козака «Мати моя старенкая» 3 3-ї інтерлюАії різдвяної Арами «Комичское АБйствіе» Митрофана Аовгалевського та в пісні Запорожця «Аа не буде кучше, Аа не буде краще, якъ у насъ Аа на Украині» 3 АванаАцятої з'яви Сокиринського вертепу.

Певні подібності у використанні музичного чинника простежуються між інтермеАією «Баба, АБА и чорт», у якій танцюють Баба і АіА, а Аемон співає «Танцуи же, бабо, танцуи, а до пекма ся готуи» та початком 2-ї Аіі вертепу, Ае також виступають АiА та Баба. Вони наміряються танцювати піА пісню «Ой пиАъ вышнею, пиАъ черешнею».

В інтермедіях шкільних драм спів хору трапляється ріАко, іноді й без зазначення, що саме він має виконувати. Так, наприклаА, в інтермедії «Тато з Сином» 3 Аернівського збірника $є$ така ремарка: «И пойдут за заслону, а хор що заспьвает» $[15$, с. 53]. У Сокиринському вертепі Хор також не був активним учасником Аіï, епізодично виконував окремі розважальні номери: пісню «Ой піА вишнею» (перша з'ява), приспіви в сцені Цигана й Циганки. Суттєвішу роль маха хорова пісня «Маты Божа, сама єАына Аа вродыла Ісуса Христа Аіва Марія» у завершальній частині вертепу, яка створювала своєріАний місток з різАвяною першою Аією.

У Аругій Аії Сокиринського вертепу, порівняно 3 жанром інтермеАій шкільних Арам, частіше використовувався музичний чинник. Він преАставлений переважно танцювальними номерами: сольними Запорожця (козачок), Кози; парними Солдата і Аарії Іванівни, Гусара і Мажарки, Поляка і Платавки (танець «Полька»), Запорожця і Феськи, Запорожця і Циганки (танець «Козачок»), ЖиАа зі своєю жінкою, КАима зі своєю жінкою; у кінці - танець «Горлиця». Аеякі танці виконувалися з піснями. ПоряА із цим існували сольні вокальні номери - Запорожця, Жила. Крім завершених музичних номерів, у восьмій з'яві 2-ї Аії вертепу виставлялася музична сценка, у якій співали Циганка та Циган, а приспів виконував Хор.

У 2-й Аії вертепу простежується зароАження тенденцій зближення українського театру з музичним фолькмором. ОАнак вертеп, що його виконували в народному середовищі й намагалися пристосуватися Ао нього, не претендував на рівень $з$ фольклором. Авторами Сокиринського вертепу були не народні музиканти, а освічені мюди з кіц Києво-Могилянської академії. Творці й постановники вертепу в XVII-XVIII ст. (очевидно, студенти, мандрівні Аяки) волоАіли теоретичними засадами поетичного мистецтва, знали український церковний спів (монодійний та партесний), канти, поширені в міському побуті, а також українську народнопісенну творчість. Вони були Аобре обізнані з текстами шкільних різАвяних драм, що регулярно виставлялися на Різдвяні свята.

У 2-й Аії вертепу на перший план виходима сміхова Аінія, музичний компонент позначе- 
ний впливами української народнопісенної інтонаційності 3 перевагою танцювамьної ритміки (зАебімьшого козачкової). Це Аає піАстави віАнести цю Аію АО низового стимьового рівня бароко. Взаємодія фомькмору 3 низовим варіантом бароко мама вемикий потенціа Аля поАамьшого розвитку української націонацьного театру.

ЗавАяки тому, що музика була невіА'ємною частиною мямькового вертепу й віАігравама важливу Араматургічну функцію, це театральне видовище мало ознаки жанру «Арама $з$ музикою». Такий жанр формувався й у шкімьній різАвяній драмі. Отже, шкімьна драма й вертеп створювами піАгрунтя, на якому в XIX ст. виникма українська драматургія зі значною ром ю в ній музичного чинника, що по суті була «Арамою з музикою», а «Наталку Полтавку» I. Котияревського називають «оперою».

Вертепне $я я$ ькове Аійство тривалий час (XIX - початок XX ст.) мало широке розповсюАження сереА українського народу, бумо умюбленим народним видовищем, яке вистав яли на РізАво в містах і селах різних регіонів України. 3 мямькової вистави вертеп іноді перетворювався на «живий» вертеп, у якому грами актори. Тексти вертепних Арам часто поширювамися в усній формі. Кімька реАакцій вертепу записано наприкінці XIX - на початку XX ст. За місцем запису вони Аістали назву «САавутинський», «Новгород-Сіверський», «Батуринський», «Хоромьський» та ін. Як свіАчать нотні записи Славутинського вертепу [9, с. 1-8], музична скмадова вже була представлена не бароковим кантовим жанром, а нескманними піснями 3 народнопісенною інтонацією. Вертеп зазнав суттєвого розвитку: віА видовища, що аАаптувало різАвяну шкімьну Араму й було пов'язане 3 освітнім сереАовищем - Києво-Могимянською акаАемією, Ао народного театру, на якому позначамися соціально-кумьтурна ситуація і процеси Аемократизації.

\section{Примітка}

${ }^{1}$ Нотні записи Сокиринського вертепу подано також у додатку до праці $\Lambda$. Корній [7, с. 355-377].

\section{Ажерема та мітература}

1. Акты и документы, относящиеся к истории Киевской Ауховной академии. Отдел. II (1791-1795) / авт. ввеА. примеч. Н. И. Петрова. Т. 4. Киев : Тип. И. И. Чоколова, 1907. XXXV + 393 с.

2. Архив Юго-Западной России : в 37 т. Т. 11. Ч. 1 :

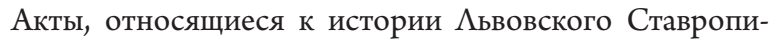
гийского братства (1586-1881 гг.). Киев : Унив. тип., 1904. 772 c.

3. Галаган Г. Малорусский вертеп. Киевская старина : исторический журнал. Київ : Тип. Г. Т. Корчак-Новицкого, 1882. Т. 4. Кн. 10: Октябрь. С. 1-38.

4. Григорій Сковорода. СаА Божественних пісень. Повна академічна збірка творів під редакцією проф. Аеоніда Ушкалова. ЕАмонд ; Торонто : ВиА-во Канадського інституту українських стуАій. Харків : МайАан, 2011. C. 51-85.

5. Євангелія віА Св. Ауки. Біблія, або Книги Святого письма Старого й Нового заповіту. Київ : Українське біблійне товариство, 1992. С. 70-112.
6. Корній $\Lambda$. П. Українська шкільна драма і духовна музика XVII - першої половини XVIII ст. / Ін-т укр. археографії. Київ, 1993. 184 с.

7. Корній $\Lambda$. Історія української музики (Аруга половина XVIII ст.). Ч. 2. Київ ; Харків ; Нью-Йорк : ВиА-во М. П. Коць, 1998.

8. Марковський Є. Український вертеп. РозвіАки й тексти : у 4 вип. Київ : ВУАН, 1929. Вип. 1.202 с.

9. Марковський Є. Український вертеп. РозвіАки й тексти. Нотний АоАаток. Ноти з рукопису Українського театрального музею. Київ : ВУАН, 1929. С. 1-40.

10. Махновець Є. Вертепна Арама. Iсторія української літератури : у 8 m. Київ : Наукова аумка, 1967. Т. 2. C. 81-88.

11. Обычаи, поверья, кухня и напитки малороссиян / извмечено из нынешнего народного быта и составцено Николаем Маркевичем. Репринтное воспроизведение издания 1860 года. Киев : Аобровольное общество мюбителей книги УССР, 1991. 
12. Петров М. І. Київська Академія. Записки історико-філологічного відділу УАН. 1919. Кн. 1. С. 3-17.

13. Софронова $\Lambda$. А. Старинный украинский театр. Москва : РОССПЭН, 1996. 327 с.

14. Сулима М. Вертепна Арама. Iсторіл української simeратури : y 12 m. Київ : Наукова Аумка, 2014. Т. 2. C. 704-711.

15. Українські інтермеАї̈ XVII-XVIII ст. / вступ. стаття і віАповіАальна реАакція М. К. ГуАзія ; піАго- товка тексту А. Є. Махновця. Київ : АН УРСР, 1960. $238 \mathrm{c}$.

16. ФеАас Й. Ю. Український народний вертеп (у АосліАженнях XIX-XX ст.). Київ : Наукова думка, 1987. $183 \mathrm{c}$.

17. Хрестоматія Аожовтневої української музики / упоряА. та коментарі О. Я. Шреєр-Ткаченко. Київ : Музична Україна, 1974. С. 101-126.

\section{References}

1. Acts and Documents Relating to the History of the Kyiv Theological Academy. Section II (1791-1795). Prefaceauthored and annotated by Nikolay PETROV. Kyiv: Ivan Ivanovych Chokolov Printing House, 1907, vol. 4, XXXV + 393 pp. [in Russian].

2. Archives of Southwest Russia: in 37 Volumes. Kiev: University's Printing House, 1904, pt. 1, vol. XI: Acts Relating to the History of the Lviv Stauropegion Brotherhood (1586-1881), 772 pp. [in Russian].

3. GALAGAN, Hryhoriy. Lesser Russian Nativity Play Drama. In: Feofan LEBEDINTSEV, ed.-in-chief, The Kyivan Past: A Historical Periodical. Kyiv: Hryhoriy KorchakNovytskyi Printing House, 1882, vol. 4, bk. 10: October, pp. 1-38 [in Russian].

4. SKOVORODA, Hryhoriy. The Garden of Divine Songs. In: Leonid USHKALOV, ed., Complete Academic Collected Works of Hryhoriy Skovoroda. T. Shevchenko Institute of Literature; $\mathrm{H}$. Skovoroda Institute of Philosophy et al. Edmonton; Toronto: Canadian Institute of Ukrainian Studies: Kharkiv: Maydan, 2011, pp. 51-85 [in Ukrainian].

5. The Gospel of St. Luke. The Bible, or the Books of Scripture of the Old and New Testaments. Kyiv: Ukrainian Bible Society, 1992, pp. 70-112 [in Ukrainian].

6. KORNIY, Lidiya. Ukrainian School Drama and Spiritual Music of the XVIIth to the First Half of the XVIIIth Century. Kyiv: NAS of Ukraine's Institute of Ukrainian Archeography, 1993, 184 pp. [in Ukrainian].

7. KORNIY, Lidiya. The History of Ukrainian Music (Latter Half of the XVIIIth Century). Part 2: A Manual. Kyiv; Kharkiv; New York: Marian-Pavlo Kots Publishing House, 1998, pp. 355-377 [in Ukrainian].

8. MARKOVSKYI, Yevhen. The Ukrainian Nativity Play Drama. Studies and Texts: in Four Issues. Kyiv: All-Ukrainian Academy of Sciences, 1929, iss. 1, 202 pp. [in Ukrainian].

9. MARKOVSKYI, Yevhen. The Ukrainian Nativity Play Drama. Studies and Texts. A Musical Addendum. Sheet Music from a Manuscript of the Ukrainian Theatrical Museum. Kyiv: All-Ukrainian Academy of Sciences, 1929, pp. 1-40 [in Ukrainian].
10. MAKHNOVETS, Leonid. The Nativity Play Drama. In: Yevhen KYRYLIUK, editorial board's chair, The History of Ukrainian Literature: in Eight Volumes. AS of Ukraine's Taras Shevchenko Institute of Literature. Kyiv: Scientific Thought, 1967, vol. 2: Formation of New Literature (Latter Half of the XVIIIth to the 1830s), pp. 81-88 [in Ukrainian].

11. MARKEVYCH, Mykola (collector and compiler). Customs, Beliefs, Cuisine, and Beverages of Lesser Russians. A reprint of the 1860 edition. Kyiv: Voluntary Society of Book Lovers of the Ukrainian SSR, 1991, pp. 27-64 [in Russian].

12. PETROV, Mykola. Kyiv Academy (On the Occasion of the Past 300th Anniversary of Its Existence). In: Pavlo ZAYTSEV, ed., Dmytro BAHALIY, ed.-in-chief, Proceedings of the Historical and Philological Department of the Ukrainian Academy of Sciences. Kyiv, 1919, bk. I, pp. 3-17 [in Ukrainian].

13. SOFRONOVA, Liudmila. The Ancient Ukrainian Theatre. RAS Institute for Slavic and Balkan Studies' Cultural History Department. Moscow: ROSSPEN, 1996, 327 pp. [in Russian].

14. SULYMA, Mykola. The Nativity Play Drama. In: Mykola SULYMA and Vira SULYMA (scientific editors). The History of Ukrainian Literature: in Twelve Volumes. NAS of Ukraine's Taras Shevchenko Institute of Literature. Kyiv: Scientific Thought, 2014, vol. 2: Ancient Literature (Latter Half of the XVIth to XVIIIth Centuries), pp. 704-711 [in Ukrainian].

15. HUDZIY, Mykola (prefaced and edited by). Ukrainian Interludes of the XVIIth-XVIIIth Centuries. Textually prepared by Leonid MAKHNOVETS. Kyiv: UkrSSR's Academy of Sciences Press, 1960, 238 pp. (Monuments of Ancient Ukrainian Literature Series) [in Ukrainian].

16. FEDAS, Yosyp. The Ukrainian Folk Nativity Play Drama (in Studies of the XIXth-XXth Centuries). Kyiv: Scientific Thought, 1987, 183 pp. [in Ukrainian].

17. SCHRÖER-TKACHENKO, Onysiya (compiler and annotator). A Reader of the Ukrainian Pre-October Music. Kyiv: Musical Ukraine, 1974, pp. 101-126 [in Ukrainian]. 